\title{
Peran Organisasi Mahasiswa Pecinta Alam dan Lingkungan Hidup Mewujudkan Universitas Negeri Padang Green campus
}

Siska Nedita Puspa, Henni Muchtar

Program Studi Pendidikan Pancasila dan Kewarganegaraan

Universitas Negeri Padang

E-mail: siskanedita26@gmail.com

\section{ABSTRAK}

Penelitian ini bertujuan untuk mendeskripsikan peran organisasi MPALH mewujudkan Universitas Negeri Padang green campus dan kendala yang dihadapi dalam pelaksanaan perannya. Organisasi MPALH merupakan organisasi internal kampus yang bergerak dalam bidang lingkungan hidup. Dengan begitu tentu saja organisasi MPALH memiliki peran dalam mewujudkan UNP green campus. Namun kenyataannya program kerja devisi lingkungan hidup organisasi MPALH banyak dilakukan di luar kampus (masyarakat). Lokasi penelitian di Universitas Negeri Padang. Jenis penelitian adalah kualitatif dengan pendekatan deskriptif. Pengumpulan data menggunakan teknik observasi, wawancara, dan dokumentasi. Hasil penelitian ini menunjukkan bahwa peran organisasi MPALH yaitu dengan melakukan kegiatan sosialisasi lingkungan dan penanaman pohon. Kegiatan sosialisasi lingkungan ada dua yaitu seminar lingkungan dan kampanye memperingati hari bumi. Selanjutnya kegiatan penanaman pohon, kegiatan penanaman pohon ada dua yaitu kegiatan rutin yang dilakukan oleh anggota organisasi Mahasiswa Pecinta Alam dan Lingkungan Hidup (MPALH) dan kegiatan Kemitraan ialah kegiatan yang bekerjasama dengan kemitraan yang lain. Kendala yang dihadapi dalam melaksanakan peran organisasi MPALH mewujudkan UNP green campus ialah sulitnya mendapatkan izin dalam melakukan penanaman pohon di lingkungan kampus, karena pihak kampus sudah memiliki bagian yang menangani mengenai penghijauan, pembangungan dan tata ruang kependudukan lingkungan UNP, program kerja organisasi MPALH orientasinya tidak pada kampus melainkan pada masyarakat, keterbatasan dana serta keterbatasan waktu.

\section{Kata Kunci: MPALH, lingkungan, UNP, green campus}

\section{ABSTRACT}

This study aims to describe the role of the MPALH organization in realizing the Universitas Negeri Padang green campus and the obstacles faced in implementing its role. The MPALH organization is an internal campus organization engaged in the environment. That way of course the MPALH organization has a role in realizing the UNP green campus. But in reality the work program of the environmental division of the MPALH organization is mostly done outside the campus (the community). This type of research is qualitative with a descriptive approach. Data collection uses observation, interview, and documentation 
techniques. The results of this study indicate that the role of the MPALH organization is to carry out environmental socialization and tree planting activities. There are two environmental socialization activities which is environmental seminar and campaign commemorating earth day. Furthermore, tree planting activities, there are two tree planting activities namely Routine Activities carried out by members of the MPALH, Partnership Activities are activities that cooperate with other partnerships. The obstacles faced in carrying out the role of MPALH's organization in realizing the UNP green campus are difficult to get permission to plant trees in the campus environment because the campus already has a section that deals with greening, development and population spatial layout of UNP. The orientation of the work program of the MPALH organization is not at UNP but on the community, limited funds, and limited time.

\section{Keywords : MPALH, environtment, UNP, green campus}




\section{PENDAHULUAN}

Lingkungan hidup adalah segala sesuatu yang ada di sekitar makhluk hidup serta mempengaruhi kehidupan baik secara langsung maupun tidak langsung. Lingkungan hidup merupakan tanggung jawab makluk hidup yang menggunakan sumber daya alam. Segala aktivitas manusia di muka bumi sangat mempengaruhi lingkungan hidup. Seiring dengan perkembangan aktivitas manusia di bumi menyebabkan semakin meningkatnya pemanasan global. Pemanasan global merupakan isu dunia utama saat ini sebagai bentuk masalah lingkungan. Munculnya masalah lingkungan tidak terlepas dari sifat manusia yang eksploitatif. Masalah lingkungan hidup global yang dialami dunia saat ini secara mendasar bersumber pada kesalahan dalam cara berpikir manusia mengenai dirinya dan alam (Astina, 2018: 2). Jadi, dapat penulis simpulkan bahwa, Lingkungan hidup adalah segala sesuatu yang ada di sekitar baik benda, manusia, hewan yang sangat mempengaruhi kehidupan termasuk dalam lingkungan kampus.

Negara-negara di dunia sudah melakukan suatu gerakan untuk penyelamatan bumi yaitu go green. Go green adalah suatu tindakan untuk penyelamatan bumi dari segala kerusakan alam yang disebabkan oleh manusia. Gerakan ini ialah penyelamatan yang dilakukan dengan program penghijauan lingkungan. Adapun program penghijauan yang sedang dilakukan di Indonesia yaitu, green city, green building dan green campus (Puspadi dkk, 2016: 2).

Jadi, dapat penulis simpulkan bahwa go green adalah gerakan penyelamatan bumi dari pemanasan global dengan cara menjaga dan melestarikan lingkungan hidup. Pada saat ini pemerintah tidak hanya fokus pada penghijauan kota, tetapi telah menuju pada pelaksanaan program green campus. Green campus didefinisikan sebagai kampus yang berwawasan lingkungan yang mengintegrasikan ilmu pengetahuan lingkungan ke dalam kebijakan, manajemen dan kegiatan tridharma perguruan tinggi. Green campus mempunyai kapasitas intelektual dan sumberdaya dalam mengintegrasikan ilmu pengetahuan dan tata nilai lingkungan ke dalam misi serta progam-progamnya. Green campus harus menjadi contoh implementasi pengintegrasian ilmu lingkungan dalam semua aspek manajemen dan best practices pembangunan berkelanjutan (Puspadi dkk, 2016:2).

Dari uraian diatas mengenai green campus dapat penulis 
simpulkan bahwa green campus adalah suatu program untuk mewujudkan kampus yang ramah lingkungan (green campus) yaitu kampus yang peduli dengan lingkungan, menjaga dan melestarikan lingkungan hidup dengan cara melakukan penghijauan penanaman pohon di lingkungan kampus yang berguna untuk menyelamatkan bumi dari pemanasan global.

Universitas Negeri Padang merupakan salah satu dari 50 universitas yang peduli lingkungan. Kepedulian UNP terhadap lingkungan hidup dapat terlihat dari penghijauan yang ada di lingkungan kampus. Karena hal tersebutlah maka pada tanggal 03 Desember 2019 Kementerian Negara Lingkungan Hidup dan Kehutanan memberikan sertifikat penghargaan 50 besar diantara 850 kampus di Indonesia yang peduli lingkungan. Penyerahan ini dihadiri oleh beberapa orang Rektor seperti Rektor UI, Rektor IPB dan pejabat Dikti (Agus Mardi, 2019 Humas UNP).

Green kampus merupakan program untuk menciptakan kampus ramah lingkungan. UNP telah melakukan penanaman pohon untuk meningkatkan kampus hijau. Kegiatan penanaman pohon merupakan bentuk kepedulian terhadap lingkungan karena semakin banyaknya masalah lingkungan yang telah menyebabkan semakin meningkatnya pemanasan global maka sangat diperlukan sekali dilakukannya penghijauan di lingkungan kampus. Hasil observasi yang penulis lakukan di UNP.

Penulis mengamati sudah banyak pohon yang tertanam di lingkungan kampus. Pohon yang ada dilingkungan kampus pada tahun 2019 meningkat dari pada tiga tahun sebelumnya. Namun masih banyak lahan yang ada di lingkungan kampus sedikit memiliki pohon. Lahan yang masih sedikit memiliki pohon ialah beberapa di fakultas diantaranya Fakultas Ekonomi (FE), Fakultas Ilmu Pendidikan (FIP), Fakultas Pariwisata dan Perhotelan (FPP), Fakultas Teknik (FT), Fakultas Bahasa dan Seni (FBS) dan Fakultas Ilmu Keolahragaan (FIK). Berikut data mengenai perkembangan penghijauan di lingkungan UNP:

\section{Penghijauan di Universitas Negeri Padang}

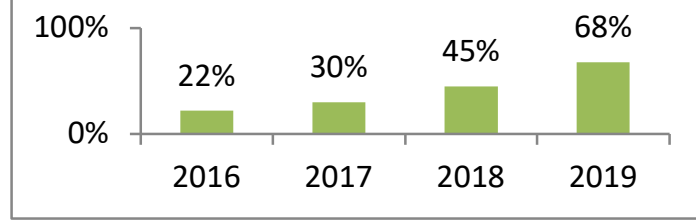

Sumber: Humas UNP Agus Mardi, 2019

Berdasarkan data

dokumentasi Humas UNP mengenai gambar diagram batang 
data perkembangan penghijauan di UNP diatas dapat dipahami bahwa dari tahun 2016 sampai tahun 2019 setiap tahunnya meningkat. Meski terus meningkat penghijauan tersebut masih saja terdapat lahan yang tidak ditanami pohon. Maka, UNP harus tetap terus melakukan penghijauan di lingkungan kampus untuk mewujudkan kampus ramah lingkungan.

Mewujudkan UNP yang ramah lingkungan bukanlah hanya sekedar program yang direncanakan Rektor. Namun untuk meningkatkan penghijauan di lingkungan kampus diperlukan partisipasi mahasiswa. Demi mewujudkan UNP green campus diperlukannya ada kesadaran akan pentingnya menjaga lingkungan kampus. Kepedulian terhadap lingkungan kampus perlu ditingkatkan lagi dengan adanya partisipasi dari kelompok mahasiswa seperti organisasi, perkumpulan, kelompok sosial dan peranan para mahasiswa karena nantinya akan menjadi pewaris lingkungan hidup yang baik. Saat ini banyak kelompok pecinta alam yang terbentuk sebagai organisasi yang bergerak dalam dunia lingkungan hidup. Organisasi tersebut pada hakikatnya bergerak dalam gerakan sosial pada permasalahan lingkungan dan peningkatan kesehatan lingkungan.
Kesadaran mahasiswa akan pentingnya melestarikan lingkungan hidup dan kepedulian mahasiswa untuk melakukan penghijauan di lingkungan kampus perlu ditingkatkan melalui pendidikan, baik formal, non formal, dan informal. Salah satunya adalah Unit Kegiatan Mahasiswa (UKM) yang terbentuk untuk menunjang perkuliahan di Perguruan Tinggi. Unit Kegiatan Mahasiswa di UNP yang berperan penting dalam bidang lingkungan hidup ialah organisasi Mahasiswa Pecinta Alam dan Lingkungan Hidup (MPALH). Organisasi ini berperan penting terhadap lingkungan hidup terutama lingkungan kampus UNP. Dengan adanya MPALH ini dapat mewujudkan UNP green campus, karena organisasi MPALH menekankan pada seruan untuk melaksanakan suatu yang baik dan melarang melakukan hal yang bisa merugikan lingkungan hidup.

Beberapa hasil penelitian terdahulu tentang green campus diantaranya berjudul "Penerapan Konsep Kampus Ramah Lingkungan (Green campus) Dalam Tinjauan Deep Ecology Di UNP" yang diteliti oleh Sela Astina, dkk tahun 2018. Penelitian kedua dengan judul "Pengembangan Indikator Peran Serta Pihak Manajemen Perguruan Tinggi Dalam Penerapan konsep Green 
campus" yang diteliti oleh Rama Putra Buana, dkk tahun 2018. Penelitian selanjutnya berjudul "Perbandingan Kendala dan Tantangan Penerapan Konsep Green campus di Itenas dan Unpar" yang diteliti oleh Puspadi N A pada tahun 2016.

implementasi Green campus

Program di Universitas Sebelas Maret diteliti oleh Yona Perwitasari pada tahun 2016. Penelitian kelima dengan judul "Kesiapan Warga Kampus UPI Menuju ECO-Campus Universitas Pendidikan Indonesia" yang diteliti oleh Raden Roby Maulidan pada tahun 2014. Penelitian keenam dengan judul "Green campus Berbasis Teknologi Informasi" yang diteliti oleh Muhammad Danur pada tahun 2016. Penelitin ketujuh dengan judul "Perencanaan dan Penganggaran Green campus Universitas Di Ponegoro" yang diteliti oleh Irma Dewi Napsari pada tahun 2014. Penelitian kedelapan dengan judul "Program ECO Campus dalam Pendidian Untuk Pembangunan

Bekerlanjutan Pada Universitas Konservasi" yang diteliti oleh Maslikhan pada tahun 2013. Penelitian kesembilan dengan judul "Persepsi Mahasiswa ITB Tentang Pengelolaan Lingkungan Di ITB Dalam Rangka Pengembangan Konsep ECO Campus" yang diteliti oleh Mochammad Chaerul, Yandi Rama Krisna dan Fazlur Rahma Hasan pada tahun 2011. Penelitian kesupuluh dengan judul "Green campus, Where You?" yang diteliti oleh Yosef Wasilah Prijotomo dan Murni Rachmawati pada tahun 2013.

Perbedaan dari beberapa hasil penelitian terdahulu adalah hanya meneliti tentang penerapan konsep green campus, green campus berbasis IT, prencanaan dan penganggaran green campus, implementasi green campus program, kesiapan menuju ecocampus, program eco-campus untuk pembangunan berkelanjutan, pengembangan konsep eco-campus. Sedangkan di penelitian ini lebih berfokus kepada peran organisasi Mahasiswa Pecinta Alam dan Lingkungan Hidup Mewujudkan UNP green campus dan kendala yang dihadapi organisasi Mahasiswa Pecinta Alam dan Lingkungan Hidup dalam mewujudkan UNP green campus.

Terdapat beberapa masalah yang ditemukan diantaranya kegiatan penanaman pohon di lingkungan kampus dilakukan hanya ketika diminta oleh pihak kampus. Kemudian pada tahun 2019 tidak ada kegiatan konservasi fauna dan flora. Begitupun pada tahun 2019 tidak ada kegiatan aksi 
bersih yang dilaksanakan di lingkungan kampus. Kegiatan sosialisasi lingkungan yang dilakukan hanyalah berupa seminar tentang pengenalan olahraga baru.

Tidak terealisasinya program kerja penghijauan organisasi Mahasiswa Pecinta Alam dan Lingkungan Hidup (MPALH). Tidak ada kegiatan pelestarian tanaman secara menyeluruh di lingkungan kampus. Selanjutnya program kerja organisasi MPALH banyak dilaksanakan di luar lingkungan kampus (masyarakat). Program kerja tahun 2019 lebih banyak mengenai pendidikan dan pelatihan anggota.

Berdasarkan permasalahan di atas hal yang sudah dilakukan oleh organisasi MPALH adalah sudah melakukan sosialisasi lingkungan kepada mahasiswa UNP, melakukan kampanye mengenai lingkungan hidup, melakukan seminar bahaya limbah plastik, dan penanaman pohon di lingkungan kampus. Namun, informan juga mengaku masih mengalami kesulitan dalam melaksanakan program kerja devisi lingkungan hidup di UNP karena berbagai hal. Salah satunya sulitnya mendapatkan izin dalam melakukan penanaman di lingkungan kampus karena pihak kampus telah memiliki bagian yang bergerak di bidang lingkungan yaitu Pusat Penelitian Kependudukan dan Lingkungan Hidup (PPKLH) Universitas Negeri Padang.

Pentingnya penelitian ini dilakukan karena MPALH sebagai organisasi internal kampus yang bergerak dalam bidang lingkungan hidup tentu memiliki peran dalam menciptakan kampus yang ramah lingkungan atau mewujudkan UNP green campus. Karena organisasi MPALH memiliki program kerja penanaman pohon dan sosialisasi lingkungan yang dapat mewujudkan UNP green campus. Berdasarkan uraian di atas sehingga penulis tertarik untuk melakukan penelitian tentang peran organisasi MPALH dalam mewujudkan UNP green campus

\section{METODE PENELITIAN}

Jenis penelitian kualitatif dengan metode pendekatan dekriptif. Lokasi penelitian ini adalah organisasi Mahasiswa Pecinta Alam dan Lingkungan Hidup di Universitas Negeri Padang. Lokasi ini dipilih untuk dijadikan tempat penelitian karena UNP merupakan salah satu dari 50 universitas yang peduli lingkungan dan memiliki organisasi yang bergerak dalam bidang lingkungan. Namun peran organisasi MPALH dalam rangka mewujudkan UNP 
green campus belum maksimal. Karena penghijauan pada ruang terbuka hijau UNP masih kurang. Dimana masih banyak fakultas yang tidak memiliki ruang terbuka hijau. Selain itu, tidak adanya pelestarian tanaman yang dilakukan oleh organisasi MPALH dalam penanaman pohon yang dilakukan dilingkungan kampus.

Informan dalam penelitian ini yaitu Wakil Rektor III UNP, Ketua Pusat Penelitian Kependudukan dan Lingkungan Hidup (PPKLH) UNP, pembina MPALH, Ketua Umum MPALH periode 2019-2020, kepala Bidang I dan 2 MPALH periode 2019-2022, Kepala Devisi Lingkungan Hidup organisasi periode 2019-2020, Ketua Umum MPALH periode 2018-2019, dan kepala Devisi Lingkungan Hidup MPALH periode 2018-2019. Teknik pengumpulan data pada penelitian ini dilakukan dengan cara wawancara, observasi, dan dokumentasi. Teknik analisis data dimulai dari pengumpulan data, reduksi data, penyajian data, dan menarik kesimpulan atau verifikasi.

\section{HASIL DAN PEMBAHASAN}

Berdasarkan temuan peneliti di lapangan bahwa devisi Lingkungan Hidup organisasi Mahasiswa Pecinta Alam dan Lingkungan Hidup (MPALH) memiliki empat program kerja yaitu aksi bersih, konservasi flora dan fauna, sosialisasi lingkungan, dan penanaman pohon. Organisasi ini sangat berperan dalam mewujudkan UNP green campus. Pada tahun 2019 program kerja aksi bersih dan konservasi flora dan fauna tidak ada dilaksanakan di lingkungan kampus. Maka penulis hanya memfokuskan pada dua program kerja yaitu sosialisasi lingkungan dan penanaman pohon. Peran organisasi MPALH mewujudkan UNP green campus yaitu dengan melakukan kegiatan sosialisasi lingkungan dan penanaman pohon.

Kegiatan sosialisasi lingkungan organisasi MPALH ada dua yaitu seminar lingkungan tentang "Bahaya Limbah Plastik" dan kampanye "Memperingati Hari Bumi". Selanjutnya melakukan kegiatan penanaman pohon. Kegiatan penanaman pohon tersebut ada dua yaitu kegiatan rutin dan kegiatan kemitraan. Kegiatan rutin ialah penanaman pohon yang dilakukan organisasi MPALH dua atau tiga kali dalam satu tahun. Penanaman tersebut dilakukan di belakang gedung PKM UNP. Kegiatan kemitraan ialah kegiatan penanaman pohon yang dilakukan dilingkungan kampus dalam rangka mewujudkan kampus ramah lingkungan (green campus) bekerjasama dengan PPKLH UNP, 
BEM UNP, MAPALA Universitas Muhamadiyah Sumatera Barat. Berikut data mengenai kegiatan kemitraan organisasi Mahasiswa Pecinta Alam dan Lingkungan Hidup (MPALH) :

Tabel 1.1 Kegiatan kemitraan organisasi MPALH

\begin{tabular}{|l|l|l|l|}
\hline No & Tanggal & Nama Kegiatan & Kemitraan \\
\hline 1. & 02 April 2018 & $\begin{array}{l}\text { Penanaman 1000 } \\
\text { pohon }\end{array}$ & $\begin{array}{l}\text { Bekerjasama dengan Pusat } \\
\text { Penelitian Kependudukan dan } \\
\text { Lingkungan Hidup (PPKLH) } \\
\text { UNP }\end{array}$ \\
\hline 2. & 02 April 2018 & $\begin{array}{l}\text { Penanaman 1000 } \\
\text { pohon }\end{array}$ & $\begin{array}{l}\text { Bekerjasama dengan } \\
\text { Lingkungan Hidup BEM UNP }\end{array}$ \\
\hline 3. & 19 Oktober 2019 & $\begin{array}{l}\text { Kegiatan sosialisasi } \\
\text { danfun orienteering }\end{array}$ & $\begin{array}{l}\text { Bekerjasama dengan FONI } \\
\text { pusat }\end{array}$ \\
\hline 4. & 19 Oktober 2019 & $\begin{array}{l}\text { Kegiatan soialisasi } \\
\text { danfum orientering }\end{array}$ & $\begin{array}{l}\text { Bekerjasama dengan FONI } \\
\text { SUMBAR }\end{array}$ \\
\hline 5. & 22 Desember 2019 & $\begin{array}{l}\text { Pelatihan pembibitan } \\
\text { dan penanaman } \\
\text { cemara laut }\end{array}$ & $\begin{array}{l}\text { Bekerjasama dengan MAPALA } \\
\text { UMSB }\end{array}$ \\
\hline
\end{tabular}

Sumber: Dokumentasi Profil MPALH, 2019

Kendala-kendala yang dihadapi dalam melaksanakan peran organisasi MPALH mewujudkan UNP green campus ialah: 1) Sulitnya mendapatkan izin dalam melakukan kegiatan penanaman pohon di lingkungan kampus karena pihak kampus sudah memiliki bagian yang mengatur mengenai tata ruang kependudukan, pembangunan dan penanaman di UNP. 2) program kerja organisasi MPALH banyak dilaksanakan diluar kampus (masyarakat), karena program kerja yang dilaksanakan setiap tahunnya berbeda-beda.

Kemudian pada tahun 2019 program kerjanya lebih banyak mengenai pendidikan dan pelatihan untuk anggota. 3). Keterbatasan dana, karena Organisasi MPALH merupakan organisasi internal kampus dan mengenai dana pelaksanaan kegiatan sudah ada porsinya masing-masing untuk setiap organisasi di UNP. 4), keterbatasan waktu, karena tugas utama seorang mahasiswa adalah belajar bukan berorganisasi. Selain berorganisasi tetap saja prioritas mahasiswa adalah kuliah. Jadi anggota organisasi MPALH harus membagi waktu untuk kuliah, berorganisasi dan kegiatan yang lainnya. Kemudian program kerja yang akan di laksanakan setiap tahunnya bukan hanya dari devisi lingkungan hidup saja tetapi juga dari devisi yang lainnya. Maka dari itu, empat program kerja devisi lingkungan hidup tidak dilaksankan semuanya setiap tahun melainkan dilaksanakan secara bergantian.

Peran organisasi MPALH tersebut belum maksimal untuk mewujudkan UNP green campus. Karena kenyataan di lapangan yang penulis temukan masih banyak lahan UNP yang tidak memiliki ruang hijau terbuka. Seharusnya organisasi MPALH lebih meningkatkan kegiatan penanaman pohon di lingkungan kampus. Karena kegiatan penanaman pohon sangat bermanfaat. Selain untuk 
mewujudkan UNP green campus atau kampus ramah lingkungan di Indonesia.

Manfaat yang lainnya ialah untuk pelestarian lingkungan, penyelamatan bumi dari pemanasan global, selain itu juga memberikan manfaat bagi warga kampus. Jika lingkungan kampus hijau, sejuk, memberikan udara yang segar tentu akan memberikan kenyamanan dalam aktivitas dan kegiatan belajar. Fakta di lapangan yang penulis temukan juga ialah masih banyak mahasiswa yang tidak mempunyai kesadaran dan kepedulian untuk menjaga lingkungan kampus. Hal tersebut dapat terlihat dari sikap mahasiswa yang masih suka membuang sampah sembarangan. Selanjutnya, masih banyak ditemukan mahasiswa yang suka memetik tanaman dan berjalan di atas tanaman. Jika hal tersebut terus terjadi akan menyebabkan kerusakan pada tanaman. Sudah seharusnya kita warga kampus menjaga lingkungan bukan malah merusaknya. Hal ini terjadi karena kurangnya sosialisasi dari organisasi MPALH kepada mahasiswa bahwa betapa pentingnya menjaga dan melestarikan lingkungan hidup. Karena lingkungan yang bersih dan sehat akan memberikan manfaat yang besar untuk diri kita sendiri. Sebagai organisasi internal kampus yang bergerak dalam bidang lingkungan sudah seharusnya untuk penanaman pohon, pelestarian tanaman, dan sosialisasi lingkungan merupakan peranan organisasi MPALH dalam mewujudkan UNP green campus.

\section{KESIMPULAN}

Hasil dari penelitian ini menunjukkan bahwa peran organisasi MPALH yaitu kegiatan sosialisasi lingkungan dan penanaman pohon. Kegiatan sosialisasi lingkungan yang dilakukan organisasi MPALH ada dua yaitu seminar tentang bahaya limbah sampah plastik dan yang kedua kampanye memperingati hari bumi. Kegiatan penanaman pohon yang dilakukan organisasi MPALH dalam menciptakan kampus ramah lingkungan di Universitas Negeri Padang ialah kegiatan rutin dan kegiatan kemitraan.

Kendala-kendala yang dihadapi organisasi Mahasiswa Pecinta Alam dan Lingkungan Hidup dalam pelaksamakan perannya mewujudkan Universitas Negeri Padang green campus yaitu, 1). Sulitnya mendapatkan izin dalam melakukan penanaman di lingkungan kampus karena UNP sudah ada bagian mengenai tata ruang kependudukan yaitu Pusat Penelitian Kependudukan dan Lingkungan Hidup (PPKLH), 2). 
Program kerja organisasi MPALH tidak berorientasi di UNP melainkan pada masyarakat, 3). Keterbatasan dana, dan 4). keterbatasan waktu.

Penelitian ini akan memberikan kontribusi terhadap bidang lingkungan hidup terutama pada mata kuliah pendidikan lingkungan hidup yang berbasis penghijauan. Pemanasan global pada saat ini semakin meningkat. Oleh sebab itu, pentingnya melakukan gerakan green campus. Organisasi MPLAH yang merupakan organisasi internal kampus yang bergerak dalam bidang lingkungan tentu saja memiliki peran besar terhadap UNP menuju green campus.

\section{DAFTAR PUSTAKA}

Astina, Sela, Iswandi Umar dan Deded Chandra. 2018. Penerapan Konsep Kampus Ramah Lingkungan (Green campus) Dalam Tinjauan

Deep Ecology Di Universitas Negeri Padang. Padang. Jurnal Buana. Nomor 5. Volume 2. E-ISSN: 2615-2630

Chaerul, Mochammad, Yandi Rama Krisna, Fazlur Hasan. 2011. Persepsi Mahasiswa ITB Tentang Pengelolaan Lingkungan Di ITB Dalam Rangka Pengembangan Konsep ECO Campus. Jurnal Penelitian Hayati UNAIR
(Accredited DIKTI), Special Edition. Nomor 46

Danuri, Muhammad. 2016. Green campus Berbasis Teknologi Informasi. Semarang. Jurnal Informasi Komunikasi. Nomor 1. H. Tan et al. / Journal of Cleaner Production 64 (2014) $646 \mathrm{e} 653$

Dewi, Irma Napsari, Nugroho Sumarjiyanto BM dan Evi Yulia Purwanti. 2014.

Perencanaan dan Penganggaran Green campus Universitas di Ponegoro. Semarang. Jurnal Teknik. Nomor 35. Volume 2. Tersedia online di: http:/ / ejournal.undip.ac.id /index.php/teknik

Dewan Pengurus Harian. 2019. Dokumentasi Profil Organisasi Mahasiswa Pecinta Alam dan Lingkungan Hidup Universitas Negeri Padang. http:/ / mpalhunp.blogspot.com/p/blogpage_19.html

Maslikhan, Maslikhan. 2013. Program ECO Campus Dalam Pendidikan Untuk Pembangunan

Berkelanjutan Pada Universitas Konservasi

Mardi, Agus. 2019. Humas Universitas Negeri Padang. 
http://unp.ac.id/id/akade mik/unp-termasuk-50kampus-peduli-lingkunganprodi-ilmu-lingkunganpascasarjana-kian-bersinar Perwitasari, Yona. 2016. Implementasi Green campus Program di Universitas Sebelas Maret. Universitas sebelas Maret.

Puspadi, N. A. 2016. Perbandingan Kendala dan Tantangan Penerapan Konsep Green campus di Itenas dan Unpar. Jurnal Online Institut Teknologi Nasional. Nomor 2. Volume 2.

Putra, Rama Buana, Mia Wimala dan Rindu Evelina. 2018. Pengembangan Indikator Peran Serta Pihak Manajemen Perguruan Tinggi dalam Penerapan Konsep Green campus. Bandung. Jurnal online Institut Teknologi Nasional. Nomor 2. Volume 4.

Roby, Raden Maulidan. 2014.

Kesiapan Warga Kampus UPI Menuju ECO- Campus Universitas Pendidikan Indonesia. Universitas Pendidikan Indonesia.

Wasilah, Yosef Prijotomo, Murni Rachmawati. 2013. Green campus, Where Are You?. Jurnal Nasional “Kota Hijau Penoir Tropis" 